\title{
Deal creates lead cloning company
}

The Roslin Institute, the UK government research center that cloned Dolly thesheep, has sold its spin-out company, Roslin BioMed, to Geron, the Californian biotech company that hit the headlineslast year for its work in isolating human embryonic stem cells. The new company, called Geron BioMed, has announced that it isexpecting the birth of the world's first cloned pig, as part of the its xenotransplantation program, within the next few months.

Dolly's creator Ian Wilmut, who spends 40 percent of his time working as a consultant to Roslin Bio-Med, will lead efforts in the new company to reprogram human cells without using eggs or creating embryos-key ethical barriers to 'spare-part' cloning.

The deal has created excitement in research and financial investment communities because it bringstogether thethree key technologies needed for human tissue cloning: Geron's human pluripotent cells and telomerase technology - which allows researchers to extend the replicative life of cells-and Roslin's nuclear transfer technology. However, Geron's chief executive, Ron Eastman, admits yet more intel lectual property will be needed to complete the technology required to produce cloned therapeutic tissue.

Clinical trials of differentiated human cell therapy could start in 2006, most likely aimed at degenerative nerve disease, but Geron is also interested in developing heart tissue and insulin-producing cells. "One challenge is which [disease] to pursue, and we may partner-out or collaborate to accelerate and broaden our work," Eastman says.

The Roslin Institute, the venture capital group $3 \mathrm{i}$, and the Bio-M ed management team have swapped their shares for Geron stock worth about $£ 30$ million (US $\$ 50$ million)-almost doubling their year-old investment.

When PPL Therapeutics-the first Roslin Institute company to be formed, focusing on the production of drugs in the milk of cloned sheep-was set up two years ago, UK research institutes were not allowed to profit from their work. New legislation has given them the ability to act as limited liability companies. But the financial size of the deal has resurrected claims that Wilmut is cashing in on government research (Nature Med. 3, 253; 1999). However, Rosl in Institute director Grahame Bulfield points out that this merely matches the rules governing universities, which are strongly encouraged to make money from their work.

Roslin Bio-Med's chief executive Simon Best told Nature Medicine that a salehad not been on theagenda when discussions with Geron started, but "the science convinced us of the need for integrated research, using [Roslin's] animal work to progress the human work." Best is keen to point out that no one was given free shares in Roslin Bio-Med. Heisdisappointed that enterprisevalueshave not yet permeated the medical community. "After all, what better motivation is there for youngsters looking at science careers?" he asks.

Geron is also interested in Roslin's animal husbandry work. As well as providing $£ 10$ million over six years for the stem cell project, Geron will provide 22.5 million for the Institute's animal research program.

Some researchers have suggested Dolly may beageing at a faster ratethan normal, and Eastman admitts the animal funding "could be" for telomerase work. "There are some issues with [Dolly's] telomeres," he acknowledges, but adds that it is not safe to draw conclusions about the ageing process of clones from a single example.

Thedramatic increasein Roslin Bio-Med's cash value is just one facet of the changes Dolly has wrought in Scotland. The number of people working in Scottish biotech-

nology has doubled in the last two years to morethan 18,000 , and the Roslin siteisnow the second-biggest employer in the Midlothian area. In April, the highly regarded annual report on European biotech by consultantsErnst \& Young cited

Central Scotland as one of only six geographical clusters that has attained the critical mass to survive and keep growing.

Medical research has been a key issuefor thepolitical parties that fought in last month's elections for Scotland's first parliament in 300 years. Nationalists portrayed the Roslin-Geron deal as a sell-out to the Americans, but the mainstream parties emphasized inward investment and job creation.

However, Scottish research science policy hangs in the balance, as the Labour Party, which failed to win an overall majority, tries to seal a power-sharing agreement with the Liberal Democrats. If it fails, the nationalist Scottish National Party, which came second, may force the devolution of science funding from the rest of the UK.

Labour has floated the idea that it will install a senior Scottish minister to oversee all aspects of science and technology, backed up by a policy board chaired by a senior scientist. A strong candidate for the job is Roslin's Bulfield, who seesthe sale of Roslin Bio-M ed to Geron as a move to put Scotland's medical research at the heart of a global effort.

\section{DAVID FIRN, LONDON}

\section{WHO hosts Web discussion on xenotransplantation policy}

This week, the World Health Organization (WHO) is launching an Electronic Discussion Group on International Xenotransplantation Policy Considerationson the World WideWeb.

Based on recommendations made at the WHO Consultation on Xenotransplantation, in October 1997, areas of discussion will include the ethical considerations of xenotransplantation; quality control for cell, tissue and organ production; donor animal health; surveillance of xenotransplant recipients and their immediate contacts; research needs and direction; and xenotransplantation registries and review boards.

A total of 13 topics will be considered in turn, and the discussion period for each will last for approximately oneweek. Background information relevant to each topic will be provided by an Organisation for Economic Co-ordination and Development archive, and a team of volunteer moderators around the world will edit submitted comments.

Moderator Andre La Prairie, manager of the Blood, Tissue, Organ and Xenograft Project Policy Division of the Canadian government, explains that the exercise is intended to inform all parties. "Regulators will learn about scientific issues and information on regulatory issues will be provided for scientists - so that they realise there are options to control xenotransplantation instead of simply calling for a moratorium," says La Prairie. He adds that it will also "be key to informing the public, because theWeb can be accessed by people from every walk of life." Those wishing to participate should send an e-mail message to xenodiscussion@who.int stating their name and affiliation.

KAREN BiRmingham, LONDON 